\title{
PERANCANGAN DESAIN ALAT PEMANENAN AIR HUJAN DENGAN MEDIA FILTER DAN PEMBANGKIT LISTRIK MIKROHIDRO (YAGIPURE)
}

\author{
FAJAR ADINUGRAHA \\ BRYAN SOEBAGIJO \\ NICOLAS ALBERT WITONO \\ BRILLIANT JOAN WONGSO \\ Fakultas Keguruan dan Ilmu Pendidikan \\ Universitas Kristen Indonesia, SMA Citra Kasih Jakarta \\ Email: fadinugraha@yahoo.co.id
}

\begin{abstract}
Abstrak. Air menjadi kebutuhan utama manusia. Ketersediaan air semakin lama semakin berkurang. Pemanenan air hujan dapat digunakan sebagai solusi cadangan air. Namun, diperlukan alat agar air hujan tersebut bisa digunakan secara optimal. Alat yang dibuat berupa alat pemanenan air hujan yang meliputi media filter dan pembangkit listrik mikrohidro. Tujuan penelitian ini adalah untuk menjelaskan perancangan, pembuatan, dan simulasi alat pemanenan air hujan yang diberi nama Yagipure. Jenis penelitian adalah penelitian rekayasa (forward engineering). Alat Yagipure ini memiliki dimensi panjang $60 \mathrm{~cm}$, lebar $40 \mathrm{~cm}$ dan tinggi 160 $\mathrm{cm}$. Media filter di dalam alat Yagipure akan mengoptimalkan air hujan sebagai cadangan air. Media filter tersusun dari sabut dengan ketebalan $10 \mathrm{~cm}$, zeolit dengan ketebalan $5 \mathrm{~cm}$, dan karbon aktif dengan kebetalan $5 \mathrm{~cm}$. Alat ini dilengkapi dengan turbin (kincir air) yang dihubungkan dengan dinamo dan aki sebagai pembangkit listrik mikrohidro. Air yang ada di bak penampungan dapat digunakan sebagai cadangan untuk kebutuhan air bersih.
\end{abstract}

Kata Kunci: pemanenan air hujan, alat yagipure, cadangan air, energi alternatif

Abstract. Water is a primary human need. The availability of water is getting in this recent time. Rainwater harvesting can be used as a water backup solution. Thus, a rain water catcher is needed to be developed and used in order to increase the water volume optimally to fulfil human need of water. The tool is basically rain water harvesting equipment which includes filter media and microhydro power plant. The objective of this research is to describe the design, manufacture, and simulating of rain water harvestin named Yagipure. The research is an engineering research - forward engineering. The Yagipure has a dimension of $60 \mathrm{~cm}$ long, $40 \mathrm{~cm}$ wide and $160 \mathrm{~cm}$ high. The filter media inside Yagipure will optimize rainwater as a water reserve. The media filters are composed of fiber with a thickness of $10 \mathrm{~cm}$, zeolite with a thickness of $5 \mathrm{~cm}$, and activated carbon with a thicknes of 5 $\mathrm{cm}$. This tool consists of a turbine (water mill) which connected by the dynamo and accu as a microhydro power plant. The water in the reservoir can be used as a reserve for clean water needs.

Key words: rain water harvesting, yagipure, water reserve, alternative energy

\section{PENDAHULUAN}

Air menjadi kebutuhan pokok hidup manusia. Semua kegiatan manusia selalu membutuhkan air. Mulai dari kegiatan rumah tangga hingga kegiatan industri membutuhkan air. Bahkan tubuh organisme juga tersusun oleh air. Ketersediaan air menjadi kebutuhan utama bagi setiap manusia. Pemerintah dan masyarakat terus mengupayakan adanya air bersih. Salah satunya adalah melalui konservasi sumber daya air. Menurut Malik (2016:1), konservasi sumber daya air memiliki arti penghematan dan penggunaan kembali (reuse) air. Hal ini menjadi 
sesuatu yang penting karena terdapat beberapa masalah terkait ketersediaan air antara lain penurunan muka air tanah, kekeringan, maupun dampak dari perubahan iklim.

Menurut Febrianto (2015: 10), keterbatasan ketersediaan air atau disebut dengan kelangkaan air disebabkan karena penggunaan air yang terus meningkat baik dari sektor pertanian, industri, rumah tangga serta perubahan iklim global. Salah satu cara untuk menghadapi kekurangan air adalah dengan cara pemanenan air hujan secara optimal. Menurut Triyono (2011) dalam Febrianto (2015:10), air hujan yang melimpah pada saat musim hujan tidak terserap seluruhnya oleh tanah. Air hujan yang tidak dapat diserap tanah akan melimpas begitu saja. Jika air limpasan ini ditampung pada suatu penampungan, maka air tersebut dapat dimanfaatkan untuk kebutuhan manusia.

Menurut Harsoyo (2010: 34-35), teknik pemanenan air hujan atau disebut dengan rain water harvesting didefinisikan sebagai suatu cara pengumpulan atau penampungan air hujan untuk selanjutnya digunakan pada waktu curah hujan rendah. Dilihat dari ruang lingkup implementasinya, teknik pemanenan digolongkan ke dalam 2 (dua) kategori yaitu: (1) teknik pemanenan air hujan dengan atap bangunan (roof top rain water harvesting), dan (2) teknik pemanenan air hujan (dan aliran permukaan) dengan bangunan reservoir, seperti dalam parit, embung, kolam, waduk dan sebagainya.

Penelitian pemanenan air hujan sudah cukup banyak dilakukan. Namun, pada artikel ini akan dibahas mengenai rancang bangun alat pemanenan air hujan yang optimal. Pemanenan air hujan yang dimaksud dalam artikel ini adalah pemanenan air hujan skala rumah tangga dengan teknik atap bangunan (roof top rain water harvesting). Hal ini dimaksud agar setiap rumah memiliki cadangan ketersediaan air sendiri.

Pemanenan air hujan sangat berpotensi dikembangkan di Indonesia, khususnya daerah kepulauan atau daerah rawa yang kekurangan ketersediaan air bersih (tawar). Selain itu, pemanenan air hujan juga sesuai diterapkan pada wilayah perkotaan. Menurut Zhang (2009) dalam Yulistyorini (2011:106), selain air bersih yang disuplai oleh PDAM, masyarakat juga menggunakan air tanah. Penggunaan air tanah yang berlebihan dan penggunaan daerah resapan air untuk pemukiman serta peruntukan sebagai tempat komersial akan menyebabkan kelangkan air tanah. Ketersediaan air hujan bisa digunakan sebagai cadangan ketika aliran penyedia air tidak lancar. Air hujan setidaknya bisa dimanfaatkan untuk mencuci, menyiram, dan kemungkinan bisa digunakan sebagai air minum.

Menurut hasil penelitan Anuar (2015: 34-36), air hujan diteliti berdasarkan parameter fisik, parameter kimiawi, parameter kimia anorganik, dan parameter mikrobiologi. Umumnya air hujan tidak berbau. Warna air hujan, total zat terlarut, kekeruhan, rasa, dan suhu di bawah baku mutu kualitas air minum yang dipersyaratkan menurut Permenkes No.492/Menkes/Per/IV/2010, sehingga dari aspek fisik air hujan bisa dikonsumsi. Berdasarkan uji parameter kimiawi, air hujan terdeteksi mengandung besi, kesadahan, klorida, mangan $\mathrm{pH}$, sulfat, tembaga, amonia, zat organik $\left(\mathrm{KMnO}_{4}\right)$ dan timbal. Berdasarkan hasil penelitian, bahwa hasil tersebut masih di bawah baku mutu kualitas air minum, sehingga secara aspek kimiawi masih bisa dikonsumsi masyarakat. Parameter kimia anorganik yang paling mendominasi adalah nitrat $\left(\mathrm{NO}_{3}{ }^{-}\right)$. Kadar nitrat ini masih di bawah baku mutu kualitas air minum sehingga masih layak dikonsumsi. Parameter mikrobilogi yaitu terdapat bakteri Eschericia coli. Kadar bakteri tersebut di atas baku mutu kualitas air minum. Hal ini kemungkinan ketika air hujan mengenai genteng akan membawa kotoran atau benda organik lain, sehingga memicu perkembangan bakteri. Oleh karena itu, diperlukan alat untuk menjaga kenetralan air hujan dan mengurangi perkembangan bakteri.

Selain kebutuhan akan air bersih, kebutuhan listrik juga menjadi hal utama. Wilayah Indonesia yang luas dan terdiri dari pulau-pulau membuat distribusi listrik tidak merata. Selain itu, di beberapa daerah perkotaan juga sering terjadi pemadaman listrik secara bergantian. Oleh karena itu, diperlukan sebuah energi alternatif sebagai sumber cadangan energi lisrik. Cadangan 
listrik yang memungkinkan dibuat di rumah penduduk adalah pemanfaatan air hujan sebagai energi alternatif. Pembangkit listrik ini disebut dengan mikrohidro.

Menurut Badaruddin (2013: 83-84), beberapa persyaratan yang harus dipenuhi untuk pembangkit listrik tenaga air mikrohidro antara lain: (1) berskala kecil yaitu hanya digunakan untuk menutupi atau mengganti kekurangan pasokan listrik PLN, (2) memiliki sungai atau sumber air sebagai sumber daya penggerak turbin/kincir, (3) memiliki debit dan beda elevasi yang mencukupi dan (4) memiliki daerah tangkapn air yang luas.

Oleh karena itu, artikel ini membahas rancang bangun alat pemanen air hujan dan pembangkit listrik mikrohidro. Alat ini diberi nama Yagipure. Artikel ini bertujuan untuk memamparkan perancangan, pembuatan, dan simulasi alat Yagipure sebagai pemanenan air hujan dan pembangkit listrik mikrohidro. Diharapkan alat ini dapat meningkatkan kualitas air hujan sebagai penyedia cadangan air bersih dan energi alternatif.

\section{METODE}

Jenis penelitian adalah penelitian rekayasa (forward engineering) yaitu rekayasa yang dilakukan dari perencanaan, pembangunan, hingga penerapan atau pada tahapan-tahapan pendek rekayasa (Maturidi, 2012: 24-25). Penelitian ini hanya memuat tentang tentang perancangan, pembuatan, dan simulasi alat Yagipure. Selanjutnya, dilakukan analisis deksripsi dengan mengkaitkan dengan studi pustaka yang relevan.

Yagipure merupakan alat pemanen dan penyaring air hujan serta pembangkit listrik alternatif mikrohidro. Penelitian ini dilakukan pada 5 Januari - 31 Maret 2015 di Laboratorium SMA Citra Kasih Jakarta.

Bahan dan alat yang digunakan dalam penelitian ini antara lain 1) Pipa PVC dengan diameter $20 \mathrm{~cm}$; 2) Turbin (kincir air) dengan diameter $20 \mathrm{~cm}$ dan jumlah sudu sebanyak 6 buah; 3) Karet ban dalam; 4) Dinamo AC; 5) Gear Roda; 6) Stainless steel; 7) Besi; 8) Sabut ketebalan $10 \mathrm{~cm}$; 9) Karbon aktif ketebalan $5 \mathrm{~cm}$; 10) Zeolit ketebalan $5 \mathrm{~cm}$; 11) Tutup tabung; 12) Bohlam lampu kecil; 13) Kabel positif negatif; dan 14) Aki.

\section{HASIL DAN PEMBAHASAN}

Teknik pemanenan air hujan yang digunakan adalah teknik dengan atap bangunan (rooftop rain water harvesting). Jadi, air hujan ditampung melalui atap rumah kemudian dialirkan ke tangki penampungan. Hal ini lebih cocok diterapkan untuk rumah yang memiliki lahan sempit terutama di perkotaan. Skema pemanenan air hujan dengan teknik atap bangunan dapat dilihat pada gambar 1.

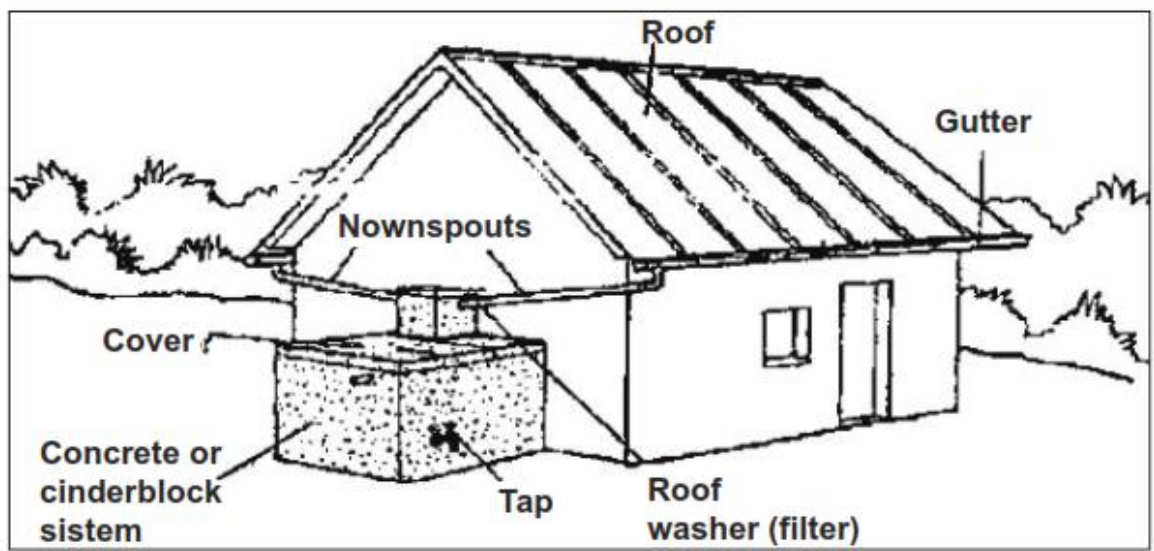

Gambar 1. Skema Teknik Panen Hujan dengan Atap Rumah (Harsoyo, 2010: 35)

Menurut Abdulla (2009), Song (2009), UNEP (2001) dalam Yulistyorini (2011), sistem pemanenan air hujan umumnya tersusun dari : (1) tempat menangkap hujan (collection area), 
(2) saluran air hujan yang mengalirkan air hukan dari tempat menangkap hujan ke tangki penyimpanan (conveyance), (3) filter, (4) reservoir (storage tank), (5) saluran pembuangan, dan (6) pompa.

Alat Yagipure ini merupakan prototype yang masih menjadi rancangan peneliti. Tujuan alat ini adalah untuk memanen air hujan dengan menyaring air hujan melalui media filter sehingga mengubah kualitas air hujan menjadi lebih baik. Selain itu, alat ini bisa dimanfaatkan sebagai energi alternatif mikrohidro meskipun dalam skala kecil. Pembuatan alat Yagipure dilakukan dengan beberapa tahapan yaitu 1) Perencanaan, 2) Pembangunan (pembuatan) dan 3) Penerapan (Simulasi). Penjelasan mengenai pembuatan alat ini dapat dijelaskan sebagai berikut:

\section{1) Perencanaan}

Kegiatan perencanaan meliputi mengumpulkan bahan dan membuat design alat Yagipure. Design alat mengalami perubahan sebanyak 2 (kali). Design alat disajikan pada gambar 2 dan 3.

Desain I (pertama), memiliki kelemahan yaitu air hujan yang keluar dari talang kurang efektif untuk menggerakkan turbin (kincir) sebagai energi alternatif. Selain itu, banyak air hujan yang terbuang karena tidak bisa jatuh ke dalam tabung penyaringan. Desain I dapat dilihat pada gambar 2.

Desain II (kedua), turbin (kincir air) dipindahkan ke bagian bawah. Air hujan masuk ke dalam tabung yang di dalamnya terdapat alat penyaringan air. Setelah itu, air akan memutar kincir, kemudian air akan masuk ke tempat penampungan. Kincir akan memutar dinamo dan mengalirkan energi ke aki. Desain II dapat dilihat pada gambar 3.
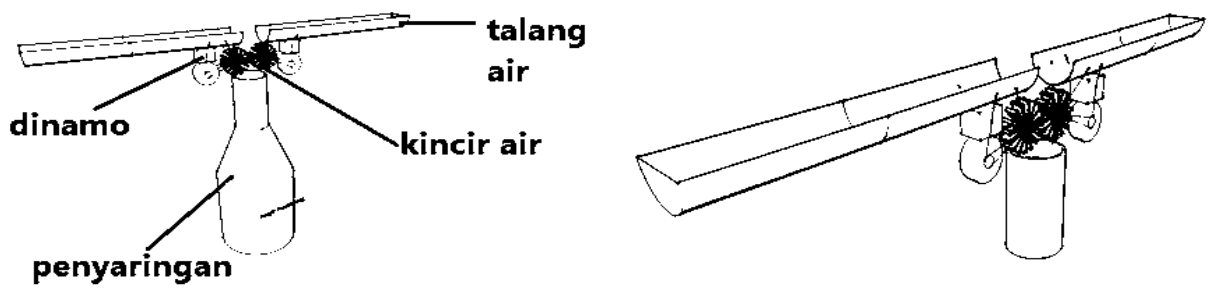

Gambar 2. Desain I Alat Yagipure

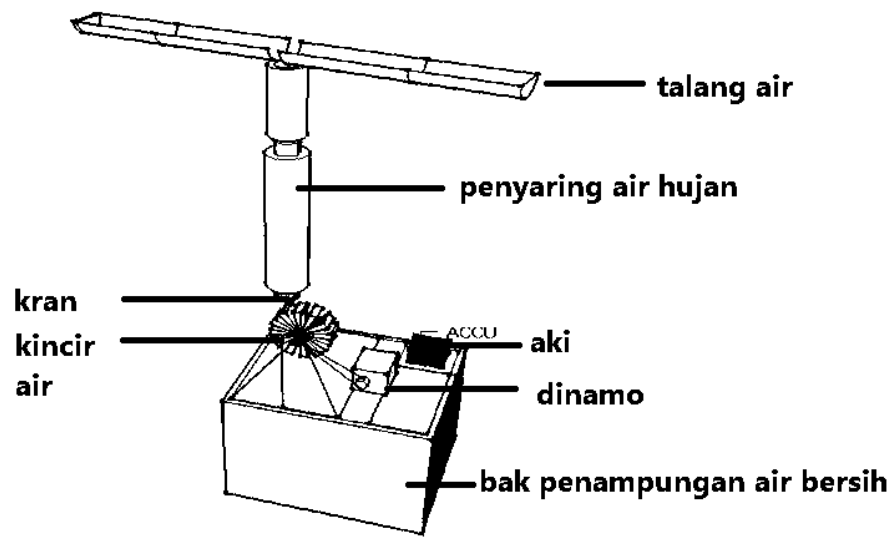

Gambar 3. Design Alat Yagipure

\section{2) Pembangunan (Pembuatan alat)}

Desain alat yaipure yang sudah dibuat dapt dilihat pada gambar 4. Pembuatan alat dimulai dengan membuat komponen utama yaitu alat penyaring air hujan yang terdiri dari pipa PVC yang di dalamnya diberi media filter sederhana. Media filter sederhana ini 
tersusun dari sabut (lapisan pertama), zeolit (lapisan kedua), dan karbon (lapisan ketiga). Media filter yang ada di dalam alat yagipure memiliki peran masing-masing. Ketebalan sabut sekitar $10 \mathrm{~cm}$, ketebalan zeolit sekitar $5 \mathrm{~cm}$, dan ketebalan arang aktif sekitar $5 \mathrm{~cm}$.

Sabut berfungsi sebagai penyaring pertama padatan yang kemungkinan terbawa oleh air hujan. Hal ini karena air hujan melalui genteng dan talang air. Sabut disebut juga sebagai filter mekanis/ fisik. Menurut Priono (2012: 77), filter ini bekerja secara mekanis sehingga fungsinya hanya menyaring kotoran, debu dan koloid. Dalam penggunaanya filter ini perlu dicuci setiap periode tertentu. Filter mekanis digunakan sebagai prafilter, yaitu filter awal sebelum air masuk ke proses filter biologi atu kimia. Hal ini disebabkan partikel besar seperti debu dan koloid tidak dapat atau sulit terposes secara kimia maupun biologis.

Zeolit termasuk ke dalam filter kimia. Menurut Kundari dan Wiyunati (2008) dalam Kendarto (2017: 55), Zeolit merupakan media filter yang dapat berfungsi sebagai absorben dan penukar ion. Zeolit dapat menyerap senyawa kimia yang meracuni air seperti amonia, $\mathrm{Se}, \mathrm{Pb}, \mathrm{Cd}$.

Karbon aktif juga termasuk filter kimia. Menurut Mifbakhudin (2010: 5), karbon aktif merupakan karbon yang diproses sehingga pori-porinya terbuka, dengan demikian memiliki daya serap tinggi. Karbon aktif merupakan karbon karbon yang bebas serta memiliki permukaan dalam (internal surface), sehingga mempunyai daya serap baik. Karbon aktif yang berwarna hitam, tidak berbau, tidak berasa akan mempunyai daya serap yang jauh lebih besar dibandingkan dengan karbon aktif yang belum menjalani proses aktivasi.

Menurut Untari (2015: 1495-1496), zeolit berperan untuk mengabsorbsi antara adsorben (zat penyerap) dan adsorbat (zat terjerat) serta menyaring zat padatan. Prinsip zeolit lain yaitu sebagai penukar ion untuk menjaga kenetralan. Karbon aktif berperan mengabsorbsi baik secara fisik maupun kimia. Zeolit dan arang aktif dapat mengabsorbsi zata terlarut penyebab rasa, warna, aroma kurang baik serta mengabsorbsi mineral dan logam berat. Menurut hasil penelitian Sutisna (2002: 270-275), kombinasi campuran arang aktif dan zeolit mampu meningkatkan kemampuan absorbsi unsur dan eliminasi bakteri Eschericia coli secar signifikan. Media filter diletakkan di bagian tengah tabung. Hal ini dimaksudkan agar air hujan yang mengalir dapat langsung melewati tabung dan tersaring di dalam pipa penyaringan. Media filter ini bisa diambil dan dibersihkan jika kondisi sudah tidak memungkinkan sebagai alat filtrasi (penyaringan).

Selanjutnya, dibuat rangka untuk meletakkan alat yagipure ini sehingga sesuai dan dapat berdiri dengan sempurna. Di bagian bawah alat dipasang kran air yang dimaksudkan apabila air sudah cukup penuh di penampugan sementara (media filter), kran air bisa dibuka dan air mengalir ke turbin (kincir air). Turbin (kincir air) ini tentunya dilengkapi dengan dinamo yang dihubungkan dengan karet ke turbin (kincir air). Hal ini bertujuan ketika air mengalir, kincir air berputar, dan selanjutnya akan menggerakkan dinamo. Dinamo yang digunakan adalah arus bolak balik (AC) atau dinamo sepeda ontel. Dari dinamo kemudian dihubungkan ke aki dan lampu.

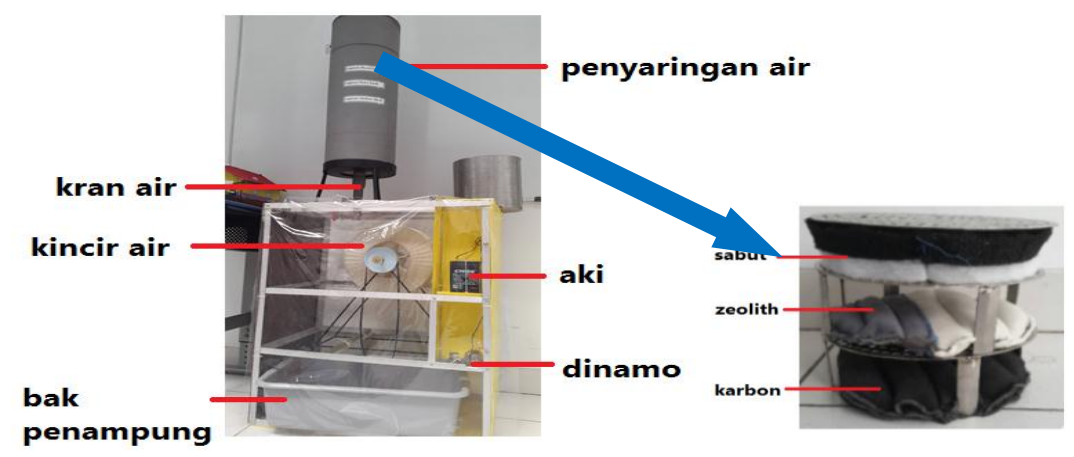


Bak penampungan diletakkan di bawah kincir. Hal ini dimaksudkan ketika air memutar kincir, air hujan tersebut akan tertampung di dalam bak penampungan. Bak penampungan ini berisi air bersih yang sudah mengalami proses filtrasi di tabung bagian atas. Kemudian air di bak penampungan ini bisa digunakan untuk keperluan manusia. Bak penampungan bisa dimodifikasi di dalam tanah atau di samping rumah sesuai dengan luas lahan masing-masing. Komponen alat dijelaskan pada tabel 1 sebagai berikut.

Tabel 1. Komponen alat Yagipure

(Pemanenan air hujan dengan media filter dan pembangkit listrik mikrohidro)

\begin{tabular}{|c|c|c|c|}
\hline \multirow{4}{*}{$\frac{l N O}{1}$} & Bagian Alat Yagipure & Gambar & Keterangan \\
\hline & $\begin{array}{l}\text { Tabung pipa dan media } \\
\text { filter (penyaring air), } \\
\text { terdiri dari } \\
\text { a. Pipa PVC }\end{array}$ & & $\begin{array}{l}\text { Berbentuk tabung } \\
\text { dengan diameter } 20 \\
\mathrm{~cm} \text { dan tinggi } 80 \mathrm{~cm} \text {, } \\
\text { dengan diberi kaki } \\
\text { untuk meletakkan pada } \\
\text { rak penyangga. }\end{array}$ \\
\hline & $\begin{array}{l}\text { b. Media filter yang } \\
\text { tersusun dari: sabut, } \\
\text { zeolith dan arang }\end{array}$ & & $\begin{array}{l}\text { Sabut }(A) \text { dengan } \\
\text { ketebalan } 10 \mathrm{~cm} \text {, } \\
\text { zeolith }(B) \text { dengan } \\
\text { ketebalan } 5 \mathrm{~cm} \text {, dan } \\
\text { arang }(C) \text { dengan } \\
\text { ketebalan } 5 \mathrm{~cm}) .\end{array}$ \\
\hline & c. Kran air & & $\begin{array}{l}\text { Kran air diletakkan } \\
\text { dibawah tabung } \\
\text { dengan tujuan apabila } \\
\text { tabung diatas sudah } \\
\text { cukup penuh kran } \\
\text { dibuka sehingga aliran } \\
\text { air akan mengalir } \\
\text { dengan cukup deras. }\end{array}$ \\
\hline 2 & Rak Penyangga & & $\begin{array}{l}\text { Rak terbuat dari } \\
\text { aluminium dengan } \\
\text { dimensi: } \\
\text { Panjang } 60 \mathrm{~cm} \\
\text { Lebar } 40 \mathrm{~cm} \\
\text { Tinggi } 80 \mathrm{~cm} .\end{array}$ \\
\hline
\end{tabular}




\begin{tabular}{|c|c|c|c|}
\hline No & Bagian Alat Yagipure & Gambar & Keterangan \\
\hline 3 & $\begin{array}{l}\text { Pembangkit listrik } \\
\text { mikrohidro, terdiri dari: } \\
\text { a. Kincir air (turbin) }\end{array}$ & & $\begin{array}{l}\text { Kincir air berdiameter } \\
20 \mathrm{~cm} \text { yang terdiri dari } \\
6 \mathrm{sudu} \text {. }\end{array}$ \\
\hline & b. Karet ban & & $\begin{array}{l}\text { Karet ban } \\
\text { dihubungkan ke } \\
\text { dinamo }\end{array}$ \\
\hline & c. Dinamo dan aki & & $\begin{array}{l}\text { Dinamo menggunakan } \\
\text { dinamo sepeda bekas } \\
\text { (B) yang kemudian } \\
\text { disambungakan ke aki } \\
\text { (A) }\end{array}$ \\
\hline & d. Lampu & & $\begin{array}{l}\text { Sebagai indikator } \\
\text { adanya arus listrik }\end{array}$ \\
\hline 4 & Bak Penampung & & $\begin{array}{l}\text { Bak penampung bisa } \\
\text { dimodifikasi menjadi } \\
\text { lebih besar karena } \\
\text { sebagai penampung air } \\
\text { bersih hasil filtrasi }\end{array}$ \\
\hline
\end{tabular}

\section{3) Penerapan (Simulasi)}

Pada dasarnya, alat Yagipure belum sepenuhnya diterapkan di rumah penduduk. Hal ini karena alat ini masih berupa prototype atau rancangan. Namun, alat ini setidaknya bisa menjadi gambaran lebih lanjut untuk penelitian selanjutnya.

Air hujan yang turun akan ditangkap oleh atap rumah. Air hujan tersebut akan mengalir melalui talang di sisi kanan kiri atap. Dari talang tersebut, air hujan tersebut akan dialirkan ke alat Yagipure (media filter). Media filter tersebut terdiri dari: 1) sabut, 2) zeolit, dan 3) arang aktif.

Air hujan yang telah disaring akan keluar lewat bawah pipa dan akan mengalir melewati turbin (kincir air) sehingga akan memutarkan turbin (kincir air). Menurut Sutriyono (2016: 236-237), turbin (kincir air) adalah gerakan putaran yang menggunakan aliran air sebagai media dengan merubah tenaga kecepatan air menjadi tenaga kinetis pada sudu atau bilah yang dirangkai dalam piringan cakram menjadi tenaga gerak putar atau torsi pada porosnya sehingga menghasilkan mekanis yang berupa gerak putar. Skema perpindahan gaya tekan menjadi gerak putar digambarkan pada gambar 5 . 
Turbin air (kincir air) tersebut dihubungkan ke dinamo dengan karet ban, sehingga ketika kincir berputar maka akan menggerakkan dinamo. Dinamo yang digunakan adalah dinamo AC (arus bolak balik). Selanjutnya, energi yang dihasilkan ditampung di dalam aki sebagai energi alternatif. Sebagai bentuk pembuktian bahwa alat ini bisa menyimpan energi dan menghasilkan listrik, disambungkan bohlam lampu ke aki. Alhasil, ketika aki sudah penuh terisi, maka listrik akan dialirkan ke bohlam lampu dan lampu akan menyala.

Pembangkit listrik dengan memanfaatkan air ini termasuk pembangkit listrik mikrohidro. Menurut Rompas (2011: 161), mikrohidro adalah istilah yang digunakan untuk instalansi pembangkit listrik yang menggunakan energi air.

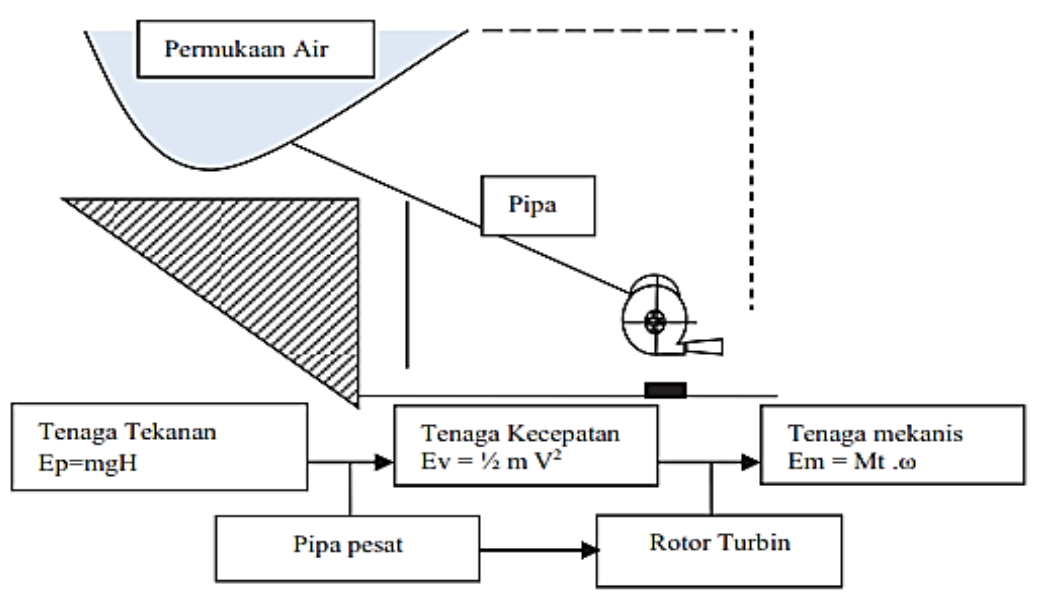

Gambar 5. Skema Perubahan Tenaga (Sutriyono, 2016:237)

Kondisi air yang bisa dimanfaatkan sebagai sumber daya penghasil listrik adalah memiliki kapasitas aliran dan ketingian tertentu. Oleh karena itu, alat ini dimbahkan kran pada penampung sementara (media filter), sehingga ketika ir dirasa sudah penuh, kran di buka dan air akan keluar memancar dan memutar turbin.

Selanjutnya, air yang memutar kincir tersebut akan masuk ke dalam bak penampungan untuk ditampung sebagai cadangan air bersih. Atau dengan istilah lain sebagai bentuk pemanenan air hujan. Dari bak penampungan tersebut, air bisa dimanfaatkan untuk kebutuhan hidup sehari-hari.

Berdasarkan UNEP (2001) dalam Yulistyorini (2011: 107), penggunaan air hujan dapat memberikan kentungan antara lain: (1) meminimalisir dampak lingkungan seperti genangan air atau banjir di sekitar rumah, (2) air hujan yang dikumpulkan relatif bersih dan kualitasnya memenuhi persyaratan sebagai air baku air bersih, (3) air hujan dapat digunakan saat kondisi darurat, terutama saat bencana atau gangguan penyediaan air mengalami kendala, (4) sebagai cadangan air bersih, pemanenan air hujan dapat mengurangi ketergantungan akan sistem penyediaan air bersih, (5) sebagai salah satu upaya konservasi, dan (6) pemanenan air hujan merupakan hal yang mudah dan fleksibel serta dapat dibangun sesuai kebutuhan.

Alat Yagipure ini sudah dicoba dengan mengalirkan air hujan ke pipa penyaringan air. Kemudian penyaringan air dibuka krannya, ketika air hujan di penyaringan air (penampungan sementara) sudah cukup penuh. Hal ini bertujuan agar air dari pipa penyaringan air keluar dengan cukup deras sehingga mampu memutar turbin dan menghasilkan energi listrik. Hal ini bisa dilihat dari lampu yang menyala yang terhubung dengan aki.

Pada artikel ini tidak membahas berapa kuat arus listrik yang dihasilkan, debit air yang dibutuhkan, serta kandungan air hujan sebelum dan sesudah melalui penyaringan. Artikel ini 
hanya membahas mengenai rancang bangun alat yang kemudian dapat diteliti atau dimodifikasi lebih lanjut untuk penelitian dan aplikasi di rumah penduduk.

\section{PENUTUP}

\section{Simpulan}

Desain alat pemanenan air hujan ini mengunakan teknik dengan atap bangunan (rooftop rain water harvesting). Alat Yagipure merupakan alat pemanenan air hujan dengan media filter (penyaringan air hujan) dan pembangkit listrik mikrohidro. Alat Yagipure ini memiliki dimensi panjang $60 \mathrm{~cm}$, lebar $40 \mathrm{~cm}$ dan tinggi $160 \mathrm{~cm}$ yang terdiri dari media filter (penyaring air hujan), rak penyangga, pembangkit listrik mikrohidro, dan bak penampungan. Media filter tersusun dari sabut dengan ketebalan $10 \mathrm{~cm}$, zeolit dengan ketebalan $5 \mathrm{~cm}$, dan karbon aktif dengan kebetalan $5 \mathrm{~cm}$. Alat pembangkit listrik mikrohidro tersusun dari turbin (kincir air) yang dihubungkan dengan dinamo dan aki. Bak penampungan digunakan sebagai tempat menampung air hujan hasil penyaringan. Air yang ada di bak penampungan dapat digunakan sebagai cadangan untuk kebutuhan air bersih.

\section{Saran}

Saran untuk penelitian selanjutnya adalah sebagai berikut: (1) perlu dilakukan uji kandungan air hujan sebelum dan sesudah melewati alat Yagipure sehingga bisa diketahui kelayakannya, (2) perlu diaplikasikan dan dicatat waktu maksimal pemanenan air hujan, dan (3) perlu diteliti arus listrik yang dihasilkan dalam jangka waktu tertentu.

\section{DAFTAR PUSTAKA}

Anuar K, Adrianto A, Sukendi. 2015. Analisis kualitas air hujan sebagi sumber air minum terhadap kesehatan masyarakat (studi kasus di kecamtan bangko bagansiapi api). Jurnal Dinamika Lingkungan Indonesia. 2 (1): 32-39.

Badaruddin B, Suwarjono JP. 2013. Sudi analisa pembangkit listrik tenaga air alternative microhydro. Jurnal Teknologi Elektro, Universitas Mercubuana. 4 (3): 82- 90.

Febrianto F, Triyono S, Rosadi RAB. 2015. Simulasi pemanenan air hujan untuk mencukupi kebutuhan air irigasi pada budidaya tanaman jagung (Zea Mays). Jurnal Teknik Pertanian Lampung. 4 (1): 9-18.

Harsoyo B. 2011. Teknik pemanenan air hujan (rain water harvesting) sebagai akternatif upaya penyelamatan sumber daya air di wilayah dki jakarta. Jurnal Sains \& Teknologi Modifikasi Cuaca. 11 (2) : 29-39.

Kendarto DR, Valentina P, Nurpilihan B, Sophia DNP. 2017. Penggunaan filter zeolit dan karbon aktif untuk menurunkan sisa klor dan penngkatn ph air hujan: studi kasus di gedung fakultas teknik industri pertanian universitas padjajaran, kecamatan jatinangor. Prosiding Seminar Nasional Fakultas Pertanian. 1 (1): 54-59.

Malik YS, Suprayogi I, Asmura J. 2016. Kajian pemanenan air hujan sebagai altenatif pemenuhan air baku di kecamatan bengkalis. Jurnal Jom F Teknik. 3 (2): 1-13.

Maturidi AD. 2012. Metode penelitian teknik informatika. Yogyakarta: Deepublish.

Mifbakhuddin M. 2015. Pengaruh ketebalan karbon aktif sebagai media filter terhadap penurunan kesadahan air sumur artesis. Jurnal Eksplanasi. 5 (2): 1 - 11.

Priono B, Satyani D. 2012. Penggunaan berbagai jenis filter untuk pemeliharan ikan hias tawar di akuarium. Jurnal Media Akuakultur. 7 (2) : 76-83.

Rompas PTD. 2011. Analisis pembangkit listrik tenaga mikrohidro (pltmh) pada daerah aliran sungai ongkak mongondow di desa muntoi kabupaten bolaang mongondow. Jurnal Penelitian Sainte. 16 (2): 160-171.

Sutisna S, Saryati S, Bambang Sugeng, Mohammad Ihsan, Siti Wardiyati, Istanto, Husen, Saleh H. 2002. Penerapan arang aktif dan zeolit untuk sistem pemurnian air minum. Prosiding 
Faktor Exacta 11 (2): 118-127, 2018

p-ISSN: 1979-276X

e- ISSN: 2502-339X

DOI: 10.30998/faktorexacta.v11i2.2377

Adinugraha F, dkk - Pembuatan Prototype Alat Yagipure....

Pertemuan Ilmiah Ilmu Pengetahuan dan Teknoogi Bahan 2002 22-23 Oktober 2002. 270-275

Sutriyono S, Trisno M. 2016. Pembangkit listrik untuk rumah tanggah dengan memfaatkan air curah hujan. Seminar Nasional Inovasi dan Aplikasi Teknologi di Industri (SENIATI). 1: 236-239

Untari T, Joni Kusnadi. 2015. Pemanfaatan air hujan sebagai air layak konsumsi di kota malang dengan metode modifikasi filtrasi sederhana. Jurnal Pangan dan Agroindustri. 3 (4): 1492-1502.

Yulistyorini A. 2011. Pemanenan air hujan sebagai alternatif pengelolan sumber daya air di perkotaan. Jurnal Teknologi dan Kejuruan. 34 (1):105-114. 